\title{
Bacterial uptake and utilization of dissolved DNA
}

\author{
Niels O. G. Jørgensen*, Carsten S. Jacobsen** \\ Microbiology Section, Department of Ecology and Molecular Biology, Royal Veterinary and Agricultural University, \\ Thorvaldsensvej 40, DK-1871 Frederiksberg C, Denmark
}

\begin{abstract}
Concentrations and bacterial uptake of extracellular dissolved DNA (D-DNA) were followed during a $2 \mathrm{wk}$ period in $5300 \mathrm{l}$ mesocosms under natural and enriched nutrient conditions in an estuary. The nutrient addition (21 $\mathrm{mg} \mathrm{Cl}^{-1}, 6 \mathrm{mg} \mathrm{N}^{-1}$ and $2.3 \mathrm{mg} \mathrm{P} \mathrm{I}^{-1}$ ) caused a 10 - to 15 -fold increase of the natural bacterial populations, followed by a rapid decline. D-DNA in the mesocosms varied from 2 to $11 \mu \mathrm{g}^{-1}$ Maximum concentrations and uptake rates of D-DNA, determined from the uptake of $\left[{ }^{3} \mathrm{H}\right]$ labelled $\lambda$ Hind DNA, coincided with the highest bacterial growth rates. Bacterial uptake of D-DNA ranged from 0.04 to $0.9 \mu \mathrm{g} \mathrm{l}^{-1} \mathrm{~h}^{-1}$ Before the nutrient additions, D-DNA was estimated to account for up to 6.8 and $46 \%$ of the bacterial $\mathrm{C}, \mathrm{N}$ and P requirements, respectively. Addition of the nutrients reduced these values to $0.8,2$ and $9 \%$, respectively. Test of uptake preference by the bacterioplankton for DNA at different sizes $(100,250$ and $569 \mathrm{bp})$ demonstrated that the smallest DNA fragment was favoured over the larger fragments. Most of the assimilated DNA was incorporated into cell constituents and could not be extracted after treatment with trichloroacetic acid. Our experiments suggest that D-DNA may be an important source of nutrients, especially phosphorus, to bacterioplankton.
\end{abstract}

KEY WORDS: Dissolved DNA - Bacterial uptake - Phosphorus

\section{INTRODUCTION}

DNA and RNA are components of all living material. During degradation of dead organic matter, nucleotides of DNA and RNA are released and taken up by microorganisms. In aquatic environments the occurrence and the bacterial assimilation of these components, especially DNA, have been studied. In marine waters about half of the pool of dissolved DNA (D-DNA) appears to be free nucleotides, while the remaining D-DNA may be in a combined form, e.g. as viral or colloidal DNA (Jiang \& Paul 1995). Addition of $\left[{ }^{3} \mathrm{H}\right] \mathrm{DNA}$ to natural water samples has demonstrated that DNA is readily taken up by bacterioplankton (Paul et al. 1989). The assimilated nucleotides may be salvaged for synthesis of new DNA (Paul et al. 1988, 1989) or serve as supplementary nutrients for bacteria (Jørgensen et al. 1993, 1994). In their studies, Jørgensen et al. $(1993,1994)$ found that D-DNA provided up to 5 and $10 \%$ of the bacterial carbon and nitrogen require-

\footnotetext{
•E-mail: nogj@kvl.dk

-Present address: Geochemical Division, Geological Survey of Denmark and Greenland, Thoravej 8, DK-2400 Copenhagen N.V., Denmark
}

ments, respectively, in batch cultures of marine bacteria. Furthermore, in phosphorus-depleted waters, DDNA may be a valuable source of phosphorus to bacteria (Turk et al. 1992).

In addition to being a potential source of nutrients and nucleotides for new DNA production, D-DNA may be involved in recombination or used for the repair of DNA. Although natural transformation followed by recombination due to gene transfer is believed to be a frequent event in bacterial communities (Lorenz \& Wackernagel 1994), experimental evidence of the importance of transformation in natural environments is scarce (Stewart 1992). However, bacterial transformation has recently been demonstrated in natural environments (Romanowski et al. 1993, Frischer et al 1994).

The uptake and the expression of functional DNA, e.g. from accidentally released bacteria, depend on various factors, for example the size of the DNA fragment. The larger the DNA fragment, the more information can be carried and the greater the possibility for production of a functional transformant. If large DNA fragments are taken up by the indigenous bacteria at the same rate as smaller pieces, they consequently represent a more likely carrier of genetic information. 
In this study we present results on incorporation of D-DNA by natural bacterioplankton in estuarine mesocosms, estimated from the uptake of $\left[{ }^{3} \mathrm{H}\right] \lambda$ Hind DNA. Some of the enclosures were enriched with glucose, ammonium and phosphate as part of a parallel study in which survival of a released bacterium (Pseudomonas fluorescens Ag1) was examined (results reported by Ahl et al. 1995). In addition to the field experiments, we studied bacterial incorporation of DNA of 3 different size groups in laboratory experiments.

\section{MATERIAL AND METHODS}

Mesocosm studies. The mesocosm experiments were conducted in enclosures of approximatoly 53001 in Roskilde Fjord in August 1992. Roskilde Fjord is a eutrophic, shallow (maximum depth $6 \mathrm{~m}$ ) water body in Eastern Zealand, Denmark. The sainity varies between 10 and $16 \%$. Water temperatures during the study periods were 16 to $19^{\circ} \mathrm{C}$. For mesocosm studies 6 transparent plastic enclosures (diameter $1.3 \mathrm{~m}$, depth $3 \mathrm{~m}$ ) were filled with natural fjord water and fixed to a wooden pontoon bridge (Nybroe et al. 1992). The following experimental setups were made:

(1) Two enclosures (referred to as ENCL +PF) in which a release of a genetically engineered microorganism was simulated by inoculation with a genetically unmodified Pseudomonas fluorescens Ag1 (Ahl et al. 1995). Simultaneously with the inoculation, $325 \mathrm{ml}$ bacterial growth medium [ingredients per litre: $10 \mathrm{~g}$ Tryptone (Difco, Detroit, USA), $4 \mathrm{~g}$ glucose, $5 \mathrm{~g}$ yeast extract and $10 \mathrm{~g} \mathrm{NaCl}$ ] was added to each enclosure. In order to stimulate growth of $P$. fluorescens in the enclosures, glucose, $\mathrm{NH}_{4}{ }^{+}$and $\mathrm{PO}_{4}{ }^{3+}$ were added after $7 \mathrm{~d}$ to give final concentrations of $21 \mathrm{mg} \mathrm{C}^{-1}, 6 \mathrm{mg} \mathrm{N} \mathrm{l^{-1 }}$ (or $430 \mu \mathrm{M} \mathrm{NH}_{4}{ }^{+}$) and $2.3 \mathrm{mg} \mathrm{Pl}^{-1}$ (or $74 \mu \mathrm{MPO}_{4}{ }^{3+}$ ), respectively. The molar ratio of the added $C, N$ and $P$ was 23.6:5.8:1

(2) Two enclosures (ENCL +PFS) similar to ENCL + PF, but the inoculation cultures of Pseudomonas fluorescens were grown repeatedly in seawater at increasing salinity to a final salinity of $14.5 \%$. Simultaneously, the growth medium concentration was reduced gradually to $0.1 \%$.

(3) Control enclosure (ENCL +CNP) to which only CNP nutrients (same concentrations as in ENCL 1 to 4 ) were added on Days 1 and 8

(4) Control enclosure (ENCL - CNP) with no additions. A detailed description of the cultivation of $P$. fluorescens Ag1 is given by Ahl et al. (1995).

At intervals of 1 or $2 \mathrm{~d}$ water samples from $0.5,1.5$ and $3.0 \mathrm{~m}$ depth were collected and mixed. Turnover rates of dissolved D-DNA were measured in mixed samples after addition of $1.5 \mathrm{ng}$ of $\left[{ }^{3} \mathrm{H}\right]$-labelled DNA (see below) in triplicate $10 \mathrm{ml}$ water samples. The samples were incubated at in situ temperature for $4 \mathrm{~h}$. Two water samples, cooled to $0^{\circ} \mathrm{C}$ in an ice bath, containing identical concentrations of $\left[{ }^{3} \mathrm{H}\right] \mathrm{DNA}$ and incubated for $4 \mathrm{~h}$, served as controls. The incubation was stopped by filtering the samples through $0.2 \mu \mathrm{m}$ Poretics filters (Poretics, Livermore, USA). The filters were rinsed with particle-free $(0.2 \mu \mathrm{m}$ filtered) Roskilde Fjord water. The radioactivity of the filters was radioassayed by liquid scintillation counting (LSC). Previous experiments indicated that formalin-killed controls as well as standard membrane filters like cellulose nitrate or acetate filters should not be used in experiments with ${ }^{3}[\mathrm{H} \mid \mathrm{DNA}$ in marine samples. We experienced very high blanks, probably due to the binding of the formalin-treated DNA to the filters (Jorgensen et al. 1993). The concentrations of D-DNA in the enclosures were determined according to Karl \& Bailiff (1989)

Laboratory studies. In August 1993, laboratory experiments with Roskilde Fjord water were performed to examine the relation between the molecular sizes of DNA fragments and bacterial uptake. The experiments were carried out with fjord water $\left(17 \%, 18^{\circ} \mathrm{C}\right)$ that had been filtered through $1.0 \mu \mathrm{m}$ membrane filters (Poretics) to remove organisms other than bacteria. The experiments were done in triplicate, using $100 \mathrm{ml}$ water when uptake of $569 \mathrm{bp}$ and 250 bp DNA fragments was studied and $50 \mathrm{ml}$ water for the study of the uptake of $100 \mathrm{bp}$ DNA fragments. Four subsamples of 4 or $6 \mathrm{ml}$ were taken after 2, 6, 10 and $24 \mathrm{~h},(569$ and $250 \mathrm{bp}$ ) or 2 and $6 \mathrm{~h}$ (100 bp) and filtered through $0.2 \mu \mathrm{m}$ Poretics filters. The available amount of $100 \mathrm{bp}$ DNA allowed only 2 sets of measurements. The filters were radioassayed by LSC. Time zero samples taken $10 \mathrm{~s}$ after addition of the DNA label were treated similarly and served as blanks. Radioactivity of the blanks was between 40 and $50 \mathrm{dpm}$.

In order to determine the amount of [ $\left.{ }^{3} \mathrm{H}\right] \mathrm{DNA}$ taken up that was incorporated in macromolecules, 2 additional subsamples were taken. After filtration through $0.2 \mu \mathrm{m}$ Poretics filters, $6 \mathrm{ml}$ of $5 \%$ trichloroacetic acid (TCA) was added on top of the filters while still mounted in the filtration funnels. After $5 \mathrm{~min}$ of extraction the filters were washed with $20 \mathrm{ml}$ of $5 \%$ TCA and radioassayed.

Ambient concentration of D-DNA was determined at the start of the experiments and after $24 \mathrm{~h}$.

Bacterial cultures. Enterobacter cloacae JP120 (Pedersen \& Jacobsen 1993) and Bacillus thuringiensis PD430 (Damgaard et al. 1996) were propagated at $150 \mathrm{rpm}, 30^{\circ} \mathrm{C}$, in Luria Bertani medium (Sambrook et al. 1989).

Labelling of DNA. Mesocosm experiments: $\lambda$-DNA cut with HindIII was heat-denatured and labelled with 
$\left[{ }^{3} \mathrm{H}\right] \mathrm{dCTP}$ (Amersham, Birkerød, Denmark) using a random primed labelling kit (Boehringer Mannheim, Germany), according to the manufacturer's instructions. Labelled DNA was purified from unincorporated nucleotides by ethanol precipitation prior to use. By LSC of excised gel fragments, approximately $85 \%$ of the labelled DNA fragments were estimated to contain between 100 and $1500 \mathrm{bp}$, and approximately $45 \%$ were in the 500 to $100 \mathrm{bp}$ range.

Laboratory experiments: DNA was extracted from bacterial cultures as described by Brousseau et al. (1993). In brief: DNA was prepared from a loopful of bacterial biomass obtained from colonies formed overnight. The cells were boiled for $10 \mathrm{~min}$ in $100 \mu \mathrm{l}$ of sterile water and centrifuged for $10 \mathrm{~min}$ at $20000 \times \mathrm{g}$ at $5^{\circ} \mathrm{C}$. By using the primers PC105 and PC106 (Table 1), a 569 bp fragment was labelled with $\left[{ }^{3} \mathrm{H}\right] \mathrm{dCTP}$. Fragments of 100 and 250 bp were generated by PCR (polymerase chain reaction) as one $350 \mathrm{bp}$ fragment using the primers EC3 and EC6 (Table 1) and subsequently digested with a restriction enzyme (see below). The $\mathrm{PCR}$ reaction mixture contained $10 \mu \mathrm{l}$ of DNA sample, $7.5 \mu$ of $\mathrm{PCR}$ buffer without $\mathrm{MgCl}_{2}$ (Perkin Elmer Cetus, Birkerød), $4 \mathrm{mM} \mathrm{MgCl}_{2}, 25 \mathrm{ng}$ of each primer (see Table 1), $0.2 \mathrm{mM}$ dATP, dTTP, dGTP (Boehringer Mannheim), $0.04 \mathrm{mM}\left[{ }^{3} \mathrm{H}\right] \mathrm{dCTP}$ (Amersham) and $1 \mathrm{U}$ AmpliTaq DNA Polymerase Stoffel Fragment (Perkin Elmer Cetus). The reaction mixture was adjusted to a total volume of $75 \mu$ l with sterile water and overlaid with 2 drops of mineral oil (Perkin Elmer Cetus). Samples were amplified in a DNA thermal cycler (Perkin Elmer Cetus) using 1 cycle of $6 \mathrm{~min}$ denaturation at $94^{\circ} \mathrm{C}, 45 \mathrm{~s}$ annealing at $55^{\circ} \mathrm{C}$, and 6 min extension at $72^{\circ} \mathrm{C}$. After this cycle, 39 cycles of $30 \mathrm{~s}$ denaturation at $94^{\circ} \mathrm{C}, 45 \mathrm{sec}$ annealing at $55^{\circ} \mathrm{C}$ and $1.5 \mathrm{~min}$ extension at $72^{\circ} \mathrm{C}$ were run, and finally an extension at $72^{\circ} \mathrm{C}$ was carried out for $15 \mathrm{~min}$. The fragments were purified by ethanol precipitation (Sambrook et al. 1989).

The labelled $350 \mathrm{bp}$ fragments were digested for $2 \mathrm{~h}$ with BamHI as recommended by the supplier (Boehringer Mannheim). The digested sample, now containing $100 \mathrm{bp}$ and $250 \mathrm{bp}$ fragments, and the larger $569 \mathrm{bp}$ fragments, was separated and purified by electrophoresis on a $2 \%$ SeaKem agarose gel (FMC Bioproducts, Hellerup, Denmark). The gel was stained with ethidium bromide, the bands were cut out quickly under UV light and the DNA was eluted from the agarose pieces by GeneClean " purification as recommended by the manufacturer (BIO-101, La Jolla, USA).

Other microbiological parameters. Bacterial production in the enclosures was measured in the mixed water samples by the incorporation of $50 \mathrm{nM}\left[{ }^{14} \mathrm{C}\right] \mathrm{leu}-$ cine (B. Riemann unpubl. data) according to Kirchman et al. (1985) and Simon \& Azam (1989). In the laboratory incubation, the incorporation of $100 \mathrm{nM}\left[{ }^{3} \mathrm{H}\right.$ ]leucine modified by Jorgensen (1992) was used. Bacterial numbers were determined by direct counting after staining in acridine orange according to Hobbie et al. (1977). Inorganic nutrients (ammonium, nitrate and ophosphate) were determined by standard autoanalyzer procedures (Technicon, Tarrytown, USA).

\section{RESULTS AND DISCUSSION}

\section{Mesocosm experiments}

Bacterial abundance and production

The release of bacteria and medium (enclosure $\mathrm{ENCL}+\mathrm{PF}$ and ENCL $+\mathrm{PFS}$ ) or medium alone (ENCL + CNP) led to a doubling of the bacterial population (from 12 to $19-24 \times 10^{6}$ cells $\mathrm{ml}^{-1}$ ) within $1 \mathrm{~d}$ (Fig. 1). The increase was not only due to the release of Pseudomonas fluorescens Ag1, as only $0.5 \times 10^{6}$ cells $\mathrm{ml}^{1}$ were added (decreasing to $<2 \times 10^{3} \mathrm{mi}^{-1}$ after $11 \mathrm{~d}$; Ahl et al. 1995). Rather, the addition of nutrients together with the bacterial cultures stimulated the growth of the indigenous bacteria. From bacterial densities of 3.9 and $10 \times 10^{6} \mathrm{ml}^{-1}$ on Days 3 to 7 , the addition of nutrients on Day 8 caused an increase to up to $140 \times 10^{6}$ bacteria $\mathrm{ml}^{-1}$ on Day 11 (Fig. 1). The nutrient addition caused a 13-fold (ENCL +PFS) to a 36-fold increase (ENCL +CNP) of the bacterial density. In the control enclosure (ENCL-CNP), the bacterial density varied from 5.1 to $11 \times 10^{6}$ cells $\mathrm{ml}^{-1}$.

The bacterial production was measured by incorporation of $\left[{ }^{14} \mathrm{C}\right.$ leucine from Day 7 to Day 15 in selected enclosures (B. Riemann unpubl, data). The production rates in ENCL +PF and ENCL +CNP varied from about 70 to

Table 1 Sequences of oligonucleotides used in $\left[^{3} \mathrm{H}\right]$-labelling of DNA. Template DNA originates from Bacillus thuringiensis PD430-16 or Enterobacter cloacae JP120

\begin{tabular}{|lll|}
\hline Oligonucleotide & Organism & Sequence \\
\hline PC105 & B. thuringiensis & 5' CGC-TAT-CAA-ATG-GAC-CAT-GG \\
PC106 & B. thuringiensis & 5' GGA-CTA-TTC-CAT-GCT-GTA-CC \\
EC 3 & E. cloacae & 5' CTG-GGC-GTA-AGC-AGC-GAT-G \\
EC 6 & E. cloacae & 5' GGT-CAG-AGA-GGT-ACC-GAA-ACC \\
\hline
\end{tabular}




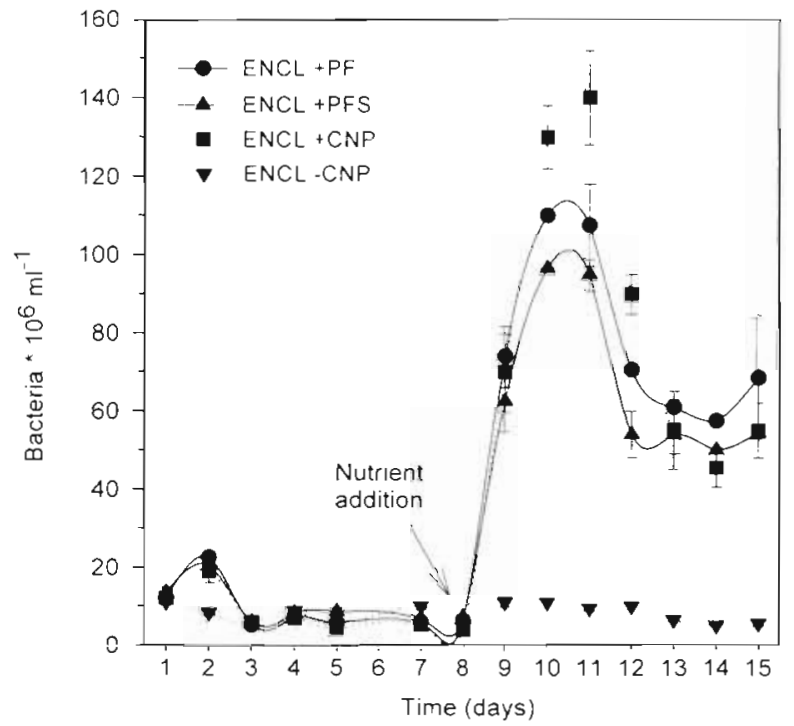

Fig. 1 Bacierld dbundance in the enclosures. On Day 1 bacteria and medium (ENCL +PF and ENCL +PFS) or only medium ( $E N C L+C N P$ ) were added to the enclosures. Enclosure ENCL -CNP was a control and did not receive any additions. Addition of nutrients (glucose, ammonium and phosphate) on Day 8 is indicated. Means \pm 1 SD shown $[n=4$, ENCL +PF and ENCL +PFS (duplicate samples from each enclosure) $\mathrm{n}=3, \mathrm{ENCL}+\mathrm{CNP}$ and ENCL -CNP|

$1100 \mu \mathrm{g} \mathrm{Cl}^{-1} \mathrm{~d}^{-1}$, with peaks on Day 9. In the control enclosure, rates from 42 to $177 \mu \mathrm{g} \mathrm{Cl}^{-1} \mathrm{~d}^{-1}$ were measured.

\section{Concentrations of D-DNA}

From Day 1 to Day 7 the concentration of D-DNA in the enriched enclosures ranged from 2 to $5 \mu \mathrm{g} \mathrm{I}{ }^{-1}$ (Fig. 2). After the nutrient addition on Day 8 , the concentration of D-DNA increased to $7 \mu \mathrm{g} \mathrm{l}^{-1}(\mathrm{ENCL}+\mathrm{PF})$ and 9 to $13 \mu \mathrm{g} \mathrm{I}^{-1}$ (ENCL +PFS and ENCL +CNP). In the control enclosure, the D-DNA content varied between 2 and $5 \mathrm{\mu g} \mathrm{l}^{-1}$. The measured D-DNA pools before the nutrient additions and in the control enclosure fall within concentrations reported for estuarine and coastal waters (DeFlaun et al. 1987, Karl \& Bailiff 1989).

The coincidence of large pools of D-DNA and an increased bacterial growth on Day 9 suggests that the D-DNA originated from bacterial activity. Actively dividing cells have been observed to release DNA (Paul et al. 1988, Paul \& David 1990). The maximum DDNA concentrations in the enriched enclosures equaled $2 \%$ of the actual bacterial DNA content, assuming $3.5 \times 10^{-15} \mathrm{~g} \mathrm{cell}^{-1}$ (Simon \& Azam 1989). This suggests that the release of DNA per bacterium was low. We assume that the D-DNA increase was due to a bacterial release, as bacteria dominated the living biomass in the enclosures on Days 9 to 12. The observed densities of $10^{8}$ bacteria $\mathrm{ml}^{-1}$ corresponded to $>15 \mathrm{mg} \mathrm{C} \mathrm{l}^{-1}$

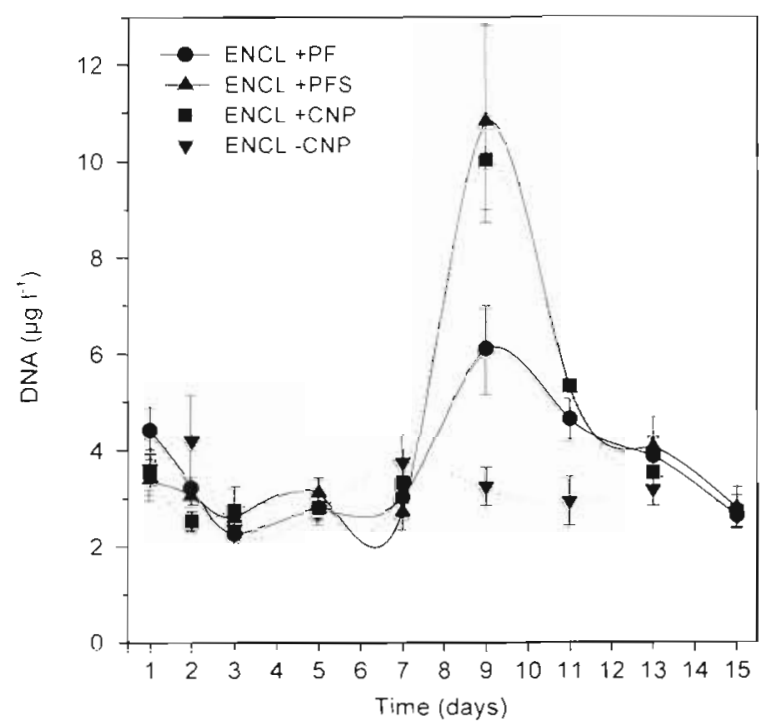

Fig. 2. Concentration of dissolved DNA (D-DNA) in the enclosures. Means $\pm 1 \mathrm{SD}$ shown $[\mathrm{n}=6, \mathrm{ENCL}+\mathrm{PF}$ and $\mathrm{ENCL}+\mathrm{PFS}$ (triplicate samples from each enclosure) $\mathrm{n}=3, \mathrm{ENCL}+\mathrm{CNP}$ and $\mathrm{ENCL}_{-}-\mathrm{CNPI}$

(Kroer et al. 1994). Heterotrophic nanoflagellate (HNF) grazing of bacteria may be expected to contribute DDNA. On most days during the study the abundance of HNF varied between 2 and $8 \times 10^{3} \mathrm{ml}^{-1}$, but a peak of $17 \times 10^{3} \mathrm{ml}^{-1}$ was observed on Day 8 (the day after the nutrient release) (Ahl et al. 1995). The potential predation by HNF was estimated to be about $40 \% \mathrm{~d}^{-1}$, implying that up to $6 \times 10^{10}$ bacteria $\mathrm{l}^{-1}$ were ingested by HNF on Day 8 . The modest D-DNA increase relative to the high bacterial biomass and the large number of cells being grazed after the nutrient addition suggest, however, that flagellate feeding was not a major source of D-DNA.

\section{Incorporation of $\left[{ }^{3} \mathrm{H}\right] \mathrm{DNA}$}

Based on turnover times of the added $\left[{ }^{3} \mathrm{H}\right] \mathrm{DNA}$, bacterial incorporation rates of natural D-DNA in the enclosures were determined. In the enriched enclosures, highly variable incorporation rates occurred. From initial mean rates of 0.4 to $0.6 \mu \mathrm{g} \mathrm{l}^{-1} \mathrm{~h}^{-1}$, the rate declined to below $0.04 \mathrm{ug} \mathrm{i}{ }^{\prime}$ ' ${ }^{\prime}{ }^{\prime}$ on Days 3 ariu' 5 (Fig. 3). The lowest rates were below the rates measured in the control enclosure (ENCL-CNP). Here the incorporation varied from 0.2 to $0.7 \mu \mathrm{g} \mathrm{I}^{-1} \mathrm{~h}^{-1}$ during the entire period. From Day 7 , the rates in the enriched enclosures increased to the level of Day 1, except in enclosure ENCL +PFS where higher values (up to $1 \mu \mathrm{g}$ $\mathrm{I}^{-1} \mathrm{~h}^{-1}$ ) occurred on Day 9. At the end of the experiment (Day 15), the incorporation rates had declined to below $0.2 \mu \mathrm{g} \mathrm{l}^{-1} \mathrm{~h}^{-1}$. 


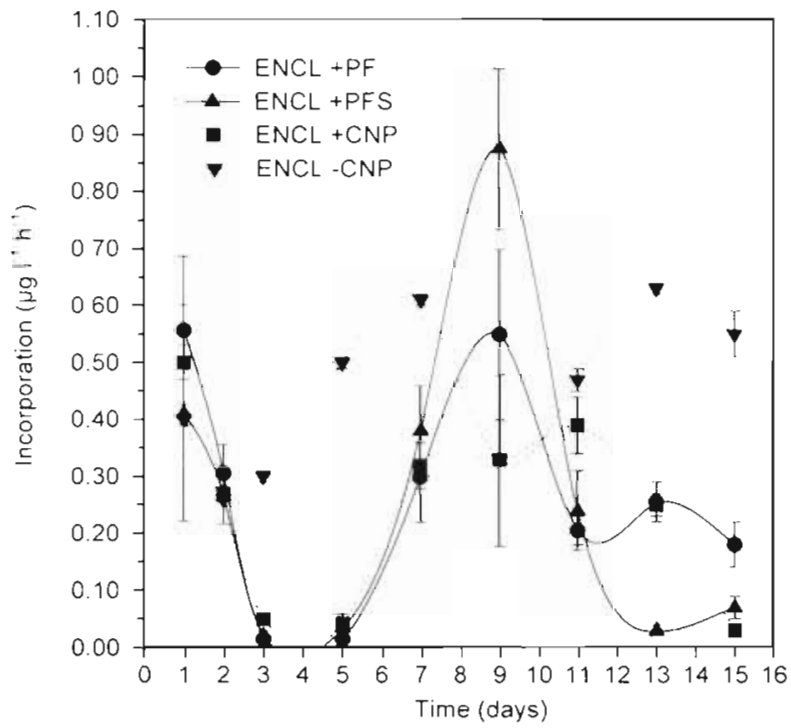

Fig. 3. Incorporation of D-DNA in the enclosures based on uptake of added [ $\left.{ }^{3} \mathrm{H}\right] \mathrm{DNA}$. Means $\pm 1 \mathrm{SD}$ shown $\mid \mathrm{n}=6$, ENCL $+\mathrm{PF}$ and $\mathrm{ENCL}+\mathrm{PFS}$ (triplicate samples from each enclosure); $\mathrm{n}=3, \mathrm{ENCL}+\mathrm{CNP}$ and ENCL $-\mathrm{CNP}]$

In the enriched enclosures, turnover times of $\left.{ }^{3} \mathrm{H}\right]$ DNA were 6 to $21 \mathrm{~h}$ from Days 1 to 3 and from Days 7 to 11 . On the other days, more variable turnover times of 31 to $267 \mathrm{~h}$ occurred. In the control enclosure ENCL -CNP, turnover times of 5 to $10 \mathrm{~h}$ (Days 1 and 7 to 15 ) and 31 to $89 \mathrm{~h}$ (Days 2 to 5 ) were measured. The average turnover time during the study period in all enclosures was $47 \pm 68 \mathrm{~h}( \pm 1 \mathrm{SD})$.

The short turnover times agreed with values $(6$ to 20 h) previously observed for bacterial DNA and nucleotides in seawater (Paul et al. 1987, 1989). The low incorporation rate on Days 3 to 5 caused a dramatic increase of the turnover time. This coincided with the 30 to $50 \%$ reduction of the D-DNA pool, relative to the initial concentrations (Fig. 2), and may indicate a change of the composition, the degradability and the production of D-DNA. Possibly the pools of bacterially available (non-combined) D-DNA were depleted during Days 1 and 2, after which more resistant D-DNA prevailed on the following days. The highest incorpo- ration rate coincided with the maximum D-DNA pools after the nutrient additions and may reflect that newly produced D-DNA was more easily degradable than DDNA present on Days 3 to 5 .

About half of the D-DNA in marine waters may be associated with colloids or be viral DNA, resistant to bacterial attack (Jiang \& Paul 1995). Other studies indicate that coated (viral) DNA can make up from $17 \%$ (Weinbauer et al. 1993) to $90 \%$ of the D-DNA (Maruyama et al. 1993). Viral DNA probably contributed to the present D-DNA pools. Observations in May 1996 showed a virus density of about $2 \times 10^{8} \mathrm{ml}^{-1}$ in the estuary ( $M$. Middelboe pers. comm.), which is comparable to other marine locations (Hennes \& Suttle 1995). Assuming a virus (bacteriophage) DNA content of $0.099 \times 10^{-15} \mathrm{~g}$ (Reanney \& Ackermann 1982), the viral DNA concentration may be estimated as $20 \mu \mathrm{ll}^{-1}$. This suggests that viruses can make up a very signifiant proportion of dissolved DNA, apparently exceeding the D-DNA concentrations measured in our enclosures. Obviously more studies are needed to determine the composition and sources of natural D-DNA.

The molecular size of $\left[{ }^{3} \mathrm{H}\right] \mathrm{D}$-DNA added to the enclosures $(85 \%$ of the DNA was between 0.1 and $1.5 \mathrm{kbp}$ ) probably represents only a portion of the size spectrum of natural D-DNA. In different waters, the size distribution of D-DNA has been found to vary from 0.1 to $35 \mathrm{kbp}$ (estuary) and from 0.2 to $14 \mathrm{kbp}$ (oligotrophic locality), with a dominance of the smaller fragments (DeFlaun et al. 1987). Since our study indicates that uptake of D-DNA varies with the size of the DNA fragments (Fig. 4, discussed below), the turnover rates measured in the present study may differ from the actual turnover rate of the total, natural D-DNA pool.

Incorporation of $\left[{ }^{3} \mathrm{H}\right] \mathrm{DNA}$ versus bacterial production

Bacterial DNA incorporation was converted to rates of carbon, nitrogen and phosphorus incorporation and was related to the bacterial production (measured on Days 7 to 15 in the ENCL +PF, ENCL +CNP and ENCL -CNP enclosures) (Table 2). In the control enclosure

Table 2. Percentage contribution (measured range) of D-DNA to the bacterial production in the enclosures. All values are based

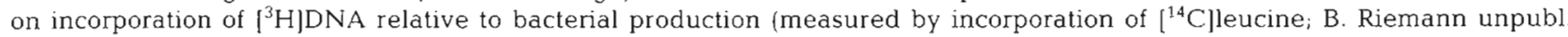
data). Bacterial carbon production was converted to $N$ and P production assuming a C:N:P ratio of 1:5:35 (Tezuka 1990). For calculation of the C, N and P contribution of incorporated DNA, a C, N and P percentage of 33, 15 and $10 \%$ of DNA, respectively, was assumed (Paul et al. 1988, or calculation of elemental composition from the chemical formulas)

\begin{tabular}{|lccccc|}
\hline & \multicolumn{2}{c}{$\begin{array}{c}\text { Before CNP addition } \\
\end{array}$} & ENCL +PF & ENCL +CNP & \multicolumn{2}{c|}{$\begin{array}{c}\text { After CNP addition (Days 9 to 12) } \\
\text { ENCL +PF }\end{array}$} & $\begin{array}{c}\text { No addition } \\
\text { ENCL +CNP }\end{array}$ & ENCL - CNP \\
\hline Carbon & $0.2-2.2$ & $1.7-3.4$ & $0.2-0.8$ & $0.3-0.5$ & $2.1-6.4$ \\
Nitrogen & $6.3-7.2$ & $3.8-8.0$ & $0.5-2.0$ & $0.7-1.1$ & $3.7-8.4$ \\
Phosphorus & $29-38$ & $17-40$ & $2.3-9.3$ & $3.0-5.0$ & $31-46$ \\
\hline
\end{tabular}


and in the remaining enclosures before the nutrient addition on Day 8 , the contribution of DNA to the net bacterial requirements of $\mathrm{C}, \mathrm{N}$ and $\mathrm{P}$ was $0.2-6.4$, $3.7-8.4$ and $17-46 \%$, respectively. After the addition of $\mathrm{C}, \mathrm{N}$ and $\mathrm{P}$, the corresponding values were $0.2-0.8$. $0.5-2.0$ and $2.3-9.3 \%$ The results indicate that under natural nutrient conditions, DNA is a minor source of $C$ and $N$, but it may provide about one third of the bacterial $P$ requirement.

The reduced uptake of D-DNA after the nutrient additions may indicate that the bacteria had a higher preference for the added low-molecular-weight nutrients than for D-DNA. Whether glucose, ammonium or phosphate caused this reduced D-DNA uptake cannot be determined from the present results. Sufficient amounts of both nitrogen and phosphorus were present during all of the study period. Initially the concentrations of $\mathrm{NH}_{4}{ }^{+}, \mathrm{NO}_{3}{ }^{-}$and $\mathrm{PO}_{4}{ }^{3-}$ were about 12,5 and $17 \mu M^{\prime}$, respectively (data noi shown). Flom Day 1 to Day $8, \mathrm{NH}_{4}{ }^{+}$was reduced to $1 \mu \mathrm{M}$, while a 30 to $60 \%$ reduction of $\mathrm{PO}_{4}{ }^{3-}$ and $\mathrm{NO}_{3}{ }^{-}$occurred. After the nutrient addition on Day $8, \mathrm{NH}_{4}{ }^{+}$and $\mathrm{PO}_{4}{ }^{3-}$ increased up to 375 and $90 \mu \mathrm{M}$, respectively. Relative to the added concentrations of $430 \mu \mathrm{M}\left(\mathrm{NH}_{4}^{+}\right)$and $74 \mu \mathrm{M}\left(\mathrm{PO}_{4}{ }^{3-}\right)$, there was a large uptake of. $\mathrm{NH}_{4}{ }^{+}$, but apparently a release of $\mathrm{PO}_{4}{ }^{3-}$. The reduction of the added $\mathrm{NH}_{4}{ }^{+}$ (from 430 to $375 \mu \mathrm{M}$ ) may not only be related to biological uptake, as the volume of the enclosures may have differed from the expected $5300 \mathrm{l}$, due to entrance of water during periods with high waves. $\mathrm{NO}_{3}{ }^{-}$ remained relatively unchanged in all enclosures after Day 8. In the control enclosure ENCL-CNP, pools of $\mathrm{NH}_{4}{ }^{+}, \mathrm{NO}_{3}{ }^{-}$and $\mathrm{PO}_{4}{ }^{3-}$ were 1-14,11-18 and 1-5 $\mu \mathrm{M}$, respectively, during the entire period.

The calculated high contribution of D-DNA (17 to $46 \%$ ) to the bacterial phosphorus demand may reflect that phosphorus was a major regulating factor for uptake of D-DNA. Previously, D-DNA has been suggested to be an important source of phosphorus for marine bacteria, but mainly in phosphorus-depleted waters (Turk et al. 1992). The phosphorus content of DDNA typically constitutes a minor portion (about $6 \%$ ) of the pool of dissolved organic phosphorus in sea water (Paul et al. 1988). The bacterial carbon contribution from D-DNA $(0.2$ to $6 \%$ ) before the nutrient addition and in the control enclosure falls within previous values obtained with a similar approach (Jørgensen et al. 1993, 1994, Kroer et al. 1994), Relative to carbon, a slightly higher contribution was estimated for nitrogen $(4$ to $8 \%$ ) in the enclosures. In cultures of marine bacteria, Jørgensen et al. (1994) found that uptake of DDNA was negatively correlated with the avajlability of nitrogen. A similar conclusion cannot be made from the present results, as both bacteria and plankton algae probably took up nitrogen in the enclosures.

\section{Uptake of DNA segments of different sizes}

Bacterioplankton from Roskilde Fjord was found to have a faster uptake of 100 basepair DNA than of 250 and 569 bp DNA (Fig. 4). The added amounts of $\left[{ }^{3} \mathrm{H}\right.$ ]DNA were $10 \mu \mathrm{g} \mathrm{l^{-1 }}$ (100 and $250 \mathrm{bp} \mathrm{DNA}$ ) and $29.1 \mathrm{~g} \mathrm{I} \mathrm{l}^{-1}$ (569 bp DNA). After 6 h of incubation, $76 \%$ of the added 100 bp size DNA was incorporated, compared to only 16 and $14 \%$ of the 250 and 569 bp DNA, respectively (Fig. 4). After $24 \mathrm{~h}, 52$ and $45 \%$ of the added 250 and 569 bp [ $\left.{ }^{3} \mathrm{H}\right] \mathrm{DNA}$, respectively, was taken up. The natural D-DNA concentrations were 12.1 to $15.7 \mu \mathrm{g} \mathrm{l}^{-1}$

The treatment of the bacteria with TCA after uptake of $569 \mathrm{bp}\left[{ }^{3} \mathrm{H}\right] \mathrm{DNA}$ for 2,6 and $10 \mathrm{~h}$ showed that $1,2.7$ and $4.3 \%$ of the $\left[{ }^{3} \mathrm{H}\right]$ label was extractable (data not shown). With 100 and 250 bp [ H]DNA, on average $2.9 \%$ (100 bp) and $2.1 \%$ (250 bp) of the DNA could be extracted after 2 and $6 \mathrm{~h}$, respectively. At the remaining incubation times, the TCA-treated samples were not statistically different from the untreated samples. Uptake of the 3 DNA segments was estimated to provide between 1 and $3 \%$ of the bacterial carbon re quirements (based on incorporation of leucine).

The TCA treatment of the bacteria showed that most of the DNA taken up was readily incorporated into cell material, although the biochemical reactions involved remain unknown. Bacterial cells can use nucleic acids in 3 different processes: transformation, DNA repair and nutrient uptake. While DNA used as a nutrient source need not be of any particular length, DNA used for transformation and in DNA repair processes must meet certain requirements. Transformation and DNA

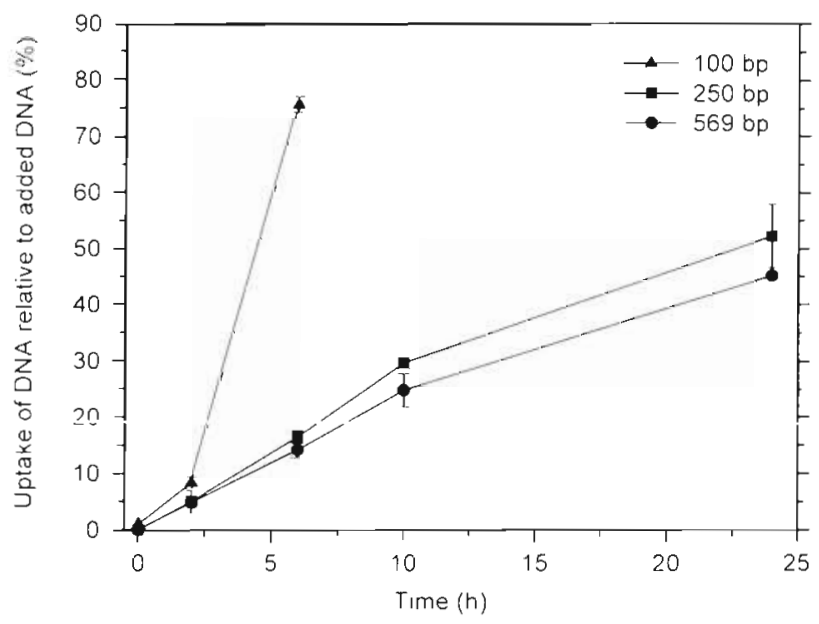

Fig. 4. Uptake relative to added 100, 250 and 569 bp [ $\left.{ }^{3} \mathrm{H}\right] \mathrm{DNA}$ in seawater from the locality of the enclosure experiment. Concentrations of the added DNA were $10 \mathrm{\mu g} \mathrm{l}^{-1}$ (100 and 250 bp DNA) and $29.1 \mathrm{pg} \mathrm{l}^{-1}$ (569 bp DNA). Means $\pm 1 \mathrm{SD}$ shown $[n=4,100$ bp DNA $i n=6,250$ and 569 bp DNA] 
repair may give the bacterium a selective force under certain (extreme) conditions, but the ability to use DNA as a nutrient source is another potentially important selective force under natural conditions. Several genes involved in the development of competence in Bacillus subtilis have been shown to be involved in nutrient uptake (Albano \& Dubnau 1989, Albano et al. 1989). If smaller pieces of DNA can be taken up by a bacterium in a non-specific way, this may explain our observation of a faster uptake of $100 \mathrm{bp}$ DNA relative to 250 and 569 bp pieces.

Uptake of small DNA pieces for nutritional purposes may not require activation of an enzyme apparatus like that needed for large DNA fragments (Albano et al. 1987). However, a 100 bp oligonucleotide corresponds to about $30000 \mathrm{Da}$, which is in fact a large molecule, and probably represents the upper limit for the trapping of molecules in the outer membrane. The exclusion limit for saccharides in outer bacterial membrane vesicles has been found to vary from $600 \mathrm{Da}$ (in Salmonella typhimurium) to 10000 Da (Pseudomonas aeruginosa PAO1) (Hancock \& Nikaido 1978). Assuming that molecular sizes of DNA and saccharides are comparable, 100 bp pieces of DNA appear to be among the largest DNA fragments that can pass through an outer bacterial membrane. If larger pieces of DNA were to be used as nutrition, the uptake would involve specific transport enzymes or extracellular nucleases.

Binding and transport of large pieces of DNA by competent bacterial cells has been studied in detail in Bacillus subtilis. Several of the gene products responsible for competence development in $B$. subtilis are membrane proteins that have been predicted to be directly involved in the processing and uptake of DNA (Hahn et al. 1993, Londoño-Vallejo \& Dubnau 1994). Another argument for uptake of DNA has been that bacterial cells primarily acquire nucleic acids for the repair of DNA (Michod et al. 1988, Hoelzer \& Michod 1991). Thus, B. subtilis was found to sustain its culturability after exposure to UV light, if a high concentration of dissolved B. subtilis DNA was present (Michod et al. 1988). Uptake of dissolved $\left[{ }^{3} \mathrm{H}\right]-D N A$, however, was not induced in growing cultures of $B$. subtilis and Haemophilus influenza by either exposure to UV light (causes damage of DNA) or treatment with mitomycin C (Redfield 1993). This observation does not support the hypothesis that the primary function of DNA uptake in bacteria is DNA repair (Redfield 1993).

Most work on the fate of D-DNA in bacterial cells has been done with very few bacterial strains, and it is uncertain whether conclusions derived from these strains can be applied to natural bacterial communities. The use of $\lambda$ Hind DNA as a tracer of dissolved DNA in our study suggests that DNA was used for nutrition, since $\lambda$-DNA has no homologies to DNA of natural bacterioplankton, and thus it cannot be directly incorporated into the chromosome.

\section{Conclusion}

Our experiments demonstrate that natural bacterioplankton is involved in cycling of D-DNA in aquatic environments. Although incorporation of the applied $\left[{ }^{3} \mathrm{H}\right] \lambda$ Hind DNA probably is not identical to that of natural D-DNA, the results suggest that a large portion of naturally occurring D-DNA can be utilized by bacterioplankton and that the assimilated DNA nutritionally may be an important source of nutrients, especially phosphorus, for bacteria.

Acknowledgements. We appreciate the technical assistance of Susan O. Jorgensen and Regitze E. Jensen during field and laboratory work. The study was supported by the Danish Environmental Protection Agency (Grant No. M 6045-0023) (N.O.G.J.) and The Danish Centre for Ecotoxicological Research (C.S.J.).

\section{LITERATURE CITED}

Ahl T, Christoffersen K, Riemann B, Nybroe O (1995) A combined microcosm and mesocosm approach to examine factors affecting survival and mortality of Pseudomonas fluorescens Ag1 in seawater. FEMS Microb Ecol 17:107-116

Albano M. Breitling $R$, Dubnau DA (1989) Nucleotide sequence and genetic organization of the Bacillus subtilis com C operon. J Bacteriol 171:5386-5404

Albano M, Dubnau DA (1989) Cloning and characterization of a cluster of linked Bacillus subtilis late competence mutations. J Bacteriol 171:5376-5385

Albano M. Hahn J, Dubnau D (1987) Expression of competence genes in Bacillus subtilis. J Bacterıol 169:3110-3117

Brousseau R, Saint-Onge A, Préfontaine G, Masson L. Cabana J (1993) Arbitrary primer polymerase chain reaction, a powerful method to identify Bacillus thuringiensjs serovars and strains. Appl Environ Microbiol 59:114-119

Damgaard PH, Jacobsen CS, Sørensen J (1996) Development and application of a primer set for specific detection of Bacllus thuringiensis and Bacillus cereus in soil using magnetic capture-hybridization and PCR amplification Syst Appl Microbiol 19:436-441

DeFlaun MF, Paul JH, Jeffrey WH (1987) Distribution and molecular weight of dissolved DNA in subtropical estuarine and oceanic environments. Mar Ecol Prog Ser 38:65-73

Frischer ME, Stewart GJ, Paul JH (1994) Plasmid transfer to indigenous marine bacterial populations by natural transformation. FEMS Microb Ecol 15:127-136

Hahn J, Inamine G, Kozlov Y, Dubnau D (1993) Characterization of comE, a late competence operon of Bacillus subtilis required for the binding and uptake of transforming DNA. Mol Microbiol 10:99-111

Hancock REW, Nikaido H (1978) Outer membranes of gramnegative bacteria. XIX. Isolation from Pseudomonas aeruginosa $\mathrm{PAO} 1$ and use in reconstitution and definition of the permeability barrier. J Bacteriol 136:381-390

Hennes KP, Suttle CA (1995) Direct counts of viruses in natural waters and laboratory cultures by epifluorescence microscopy. Limnol Oceanogr 40:1050-1055 
Hobbie JE, Daley RJ, Jasper S (1977) Use of Nuclepore filters for counting bacteria by fluorescent microscopy. Appl Environ Microbiol 33:1225-1228

Hoelzer MA, Michod RE (1991) DNA repair and the evolution of transformation in Bacillus subtilis. III. Sex with damaged DNA. Genetics 128:215-223

Jiang SC, Paul JH (1995) Viral contribution to dissolved DNA in the manne environment as determined by differential centrifugation and kingdom probing. Appl Environ Microbiol 61:317-325

Jørgensen NOG (1992) Incorporation of $\left[{ }^{3} \mathrm{H}\right]$ leucine and $\left[{ }^{3} \mathrm{H}\right]$ valine into protein of freshwater bacteria: uptake kinetics and intracellular isotope dilution. Appl Environ Microbiol 58:3638-3646

Jørgensen NOG, Kroer N, Coffin RB (1994) Utilization of dissolved nitrogen by heterotrophic bacterioplankton. Effect of substrate $\mathrm{C} / \mathrm{N}$ ratio. Appl Environ Microbiol 60: $4124-4133$

Jørgensen NOG, Kroer N. Coffin RB, Yang XH, Lee C (1993) Dissolved free amino acids, combined amino acids, and DNA as sources of carbon and nitrogen to marine bacteria. Mar Ecol Prog Ser 98:135-148

Kaxl DM, Bailiff MD (1989) The measurement and distribution of nucleic acids in aquatic environments. Limnol Oceanogr 34:543-558

Kirchman DL, K'Nees E, Hodson RE (1985) Leucine incorporation and its potential as a measure of protein synthesis by bacteria in natural aquatic systems. Appl Environ Microbiol 49:599-607

Kroer N, Jørgensen NOG, Coffin RB (1994) Utilization of dissolved nitrogen by heterotrophic bacterioplankton. A cross ecosystem analysis. Appl Environ Microbiol 60: $4116-4123$

Londoño-Vallejo JA, Dubnau D (1994) Membrane association and role in DNA uptake of the Bacillus subtilis PriA analogue ComF1. Mol Microbiol 13:197-205

Lorenz MG, Wackernagel W (1994) Bacterial gene transfer by natural genetic transformation in the environment. Microb Rev 58:426-465

Maruyama A. Oda M, Higashihara T (1993) Abundance of virus-sized non-DNase digestible DNA (coated DNA) in eutrophic seawater. Appl Environ Microbiol 59:712-717

Michod RE, Wojciechowski MF, Hoelzer MA (1988) DNA repair and the evolution of transformation in the bacterium Bacillus subtilis. Genetics 118:31-39

Nybroe O, Christoffersen K, Riemann B (1992) Survival of Bacillus licheniformis in seawater model ecosystems. Appl Environ Microbiol 58:252-259

Responsible Subject Edıtor: F. Thingstad, Bergen, Norway
Paul JH, David AW (1990) Production of extracellular nucleic acids by genetically altered bacteria in aquatic-environment microcosms. Appl Environ Microbiol 55:1865-1869

Paul JH, DeFlaun MF, Jeffrey WH, AW David (1988) Seasonal and diel variability in dissolved DNA and in microbial biomass and activity in a subtropical estuary. Appl Environ Microbiol 54:718-727

Paul JH, Jeffrey WH, David AW, DeFlaun MF, Cazares LH (1989) Tumover of extracellular DNA in eutrophic and oligotrophic environments of southwest Florida. Appl Environ Microbiol 55:1823-1828

Paul JH, Jeffrey WH, DeFlaun MF (1987) Dynamics of extracellular DNA in the marine environment. Appl Environ Microbiol 53:170-179

Pedersen JC, Jacobsen CS (1993) Fate of Enterobacter cloacae JP120 and Alcaligenes eutrophus AEO106(pRO101) in soil during water stress: effects on culturability and viability. Appl Environ Microbiol 59:1560-1564

Reanney DC, Ackermann HW (1982) Comparative biology and evolution of bacteriopnages. Adv Virus Fes 27:205-260

Redfield RJ (1993) Evolution of natural transformation: testing the DNA repair hypothesis in Bacillus subtilis and Haemophilus influenzae, Genetirs 1.33:755-761

Romanowskı G, Lorenz MG, Wackernagel W (1993) Plasmid DNA in a groundwater aquifer microcosm - adsorption, DNAase resistance and natural genetic transformation of Bacillus subtilis. Mol Ecol 2:171-181

Sambrook J, Fritsch EF, Maniatis T (1989) Molecular cloning: a laboratory manual, 2nd edn. Cold Spring Harbor Laboratory, Cold Spring Harbor, NY

Simon M, Azam F (1989) Protein content and protein synthesis of planktonic marine bacteria. Mar Ecol Prog Ser 51: 201-213

Stewart GJ (1992) Transformation in natural environments. In: Wellington $E M H$, van Elsass JD (eds) Genetic interactions among microorganisms in the natural environment. Pergamon Press, Oxford, p 216-234

Tezuka Y (1990) Bacterial regeneration of ammonium and phosphate as affected by the carbon:nitrogen phosphorus ratio of organic substrates. Microb Ecol 19:227-238

Turk V, Rehnstam AS, Lundberg E, Hagström \& (1992) Release of bacterial DNA by marine nanoflagellates, an intermediate step in phosphorus regeneration. Appl Environ Microbiol 58:3744-3750

Weinbauer MG, Fuks D, Peduzzi P (1993) Distribution of viruses and dissolved DNA along a coastal trophic gradient in the northern Adriatic Sea. Appl Environ Microbiol 59:4074-4082

Manuscript furst received: January 15, 1996 Revised version accepted: October 3,1996 